\title{
Inflamatory Chemistry and Organic Surgery in the Maxilar Compression
}

\author{
CONSTANTIN MIHAI ${ }^{1}$, CRISTIAN CONSTANTIN BUDACU ${ }^{1 *}$, VLAD DANILA ${ }^{1 *}$, DRAGOS OCTAVIAN PALADE ${ }^{2 *}$, MIHAELA DEBITA ${ }^{3}$, \\ CIPRIAN DINU ${ }^{3}$, MIHAI LIVIU CIOFU ${ }^{1}$, MIHAIL BALAN ${ }^{1}$ \\ ${ }^{1}$ Grigore T. Popa University of Medicine and Pharmacy, Faculty of Dental Medicine, 16 Universitatii Str., 700115, Iasi, Romania \\ ${ }^{2}$ Grigore T. Popa University of Medicine and Pharmacy, Faculty of General Medicine, 16 Universitatii Str., 700115, Iasi, Romania \\ ${ }^{3}$ Dunarea de J os University of Galati, Faculty of Medicine and Pharmacy, 47 Domneasca Str., 800008, Galati, Romania
}

\begin{abstract}
The morphology and physiology of odonto-periodontal units, muscles, temporomandibularjoints, maxillary bones, ligaments are in a constant balance, even if all these components are subject to continuous transformation. Affecting a systemic element will attract imbalances to other levels, and the therapeutic solution will require knowledge and understanding of the ensemble. A complete dental exam must allow identification of all factors responsible or likely to cause imbalance in the stomatognat system. The maxillary compression is an abnormality characterized by a transversal developmental deficiency in the upper jaw and / or the mandibular, showing morpho-functional changes that denote a complex disruption in the development of the dento-maxillary apparatus. The common modification of all the fractured cases is the insufficient development in a transversal sense, dental arcades (mono - or bimaxilar), along with facial and maxillary bone changes, disturbances of inter-maxillary or occlusion blocking, functional deficits and disturbances. The strictly mandibular compression situation is very rare and addresses cases by affecting growth at the condylian level. The study includes 27 cases with jaw compression and benefited from orthognat surgery in the Maxillofacial Surgery Clinic between 2015 - 2018. If untreated, the abnormality determines the appearance of many cavities especially in the front teeth, difficulty in performing dental hygiene will lead to chronic marginal periodontitis, the occurrence of abnormal contact between teeth with joint pain, decreased chewing field. The jaw compression is revealed by multiple facial and oral signs, as well as by functional changes. Orthognatic surgery is the only effective treatment for many patients in jaw compression.
\end{abstract}

\section{Keywords: maxillary compression, surgical treatment, orthognatic surgery}

The accentuated inclination of the upper teeth is the most common orthodontic problem, being a symptom of jaw compression. This anomaly occurs in children with ENT problems (polyps, frequent tonsillitis) and is associated with oral breathing (cause-and-effect relationship). These children have pale teguments, the nostrils are narrow with a low tonus, they keep their mouth open, leaving the upper incisors visible behind the lower lip, the convex profile being characteristic in disturbing the facial appearance[ 1-3].

Higher incisors are prematurely affected by carious processes and trauma due to their exposure outside the oral cavity. In more severe cases, there are also masticatory disorders, accompanied by a retardation in the general growth and development of the child, which is often noted by the pediatrician. The maxillary compression is the dento-maxillary abnormality that is most frequent in patients in Romania [4-6].

Studies of 7-14-year-old children found that $31.8 \%$ of this condition was found. The abnormality can be highlighted during all three periods of dentition (temporary, mixed, permanent). The development of the mandible is done through condylar cartilage which is a secondary growth cartilage (active up to 20-25 years). It is often compared to the epiphyseal cartilage of a developing long bone. It consists of a proliferative layer of progeny cells for growth cartilage. These cells become condroblasts and develop an extracellular matrix of proteoglycans and type II collagen to form the extracellular matrix of the cartilage. At the same time there is a hypertrophy of the condroblasts followed by encondral ossification involving cartilage mineralization, vascular invasion, chondrocyte loss and differentiation of osteoblasts to produce bone on the mineralized cartilage matrix. The only difference, but with a key significance in this process between condylian and epiphyseal cartilage, is the absence of cartilage cells arranged in columns (long bone characteristic).

This arrangement determines the unidirectional development of the epiphyseal bone, while in contrast, the condyle cartilage can proliferate in any direction for the correctanatomical spatial positioning of the mandible arch. It is now recognized that the development and growth of the condylian is not primary but compensatory and adaptive, (Mac Namara and Moss) being the functional matrix concept [7-9].

Ten Cate also mentions the existence of a transient growth cartilage associated with the development of the articular tuberculum. There are no temporal tuberculums at birth, which are formed from the grow cartilage similar to that of the condylian. At the time of clinical examination of the posture relationship, the articular marker: is normal in the case of the sagittal rotation of the mandible, but there is a previous translation of the orbital condylar in horizontal rotation, anterior or posterior to bilateral translation for cases where the mandible translates forward, respectively posterior.

J oint symptoms such as joint pain of different degrees, local, referenced or psychogenic, joints and joint crepitation, articular jump, static or dynamic deviation of the mandible, subluxation may also occur.The mandible and maxilla should develop at the same time. But during growth, one or both can deviate in several ways. People who have a convex profile, that is a very large jaw in the back - fall into Class II - that means lower teeth are more behind than

\footnotetext{
* email: cristibudacu@yahoo.com; vlad.danila@umfiasi.ro; drpalade@gmail.com
} 
those on the upper jaw. In the reverse situation, this is a Class III relationship. The mandible stops growing from one side, which will lead the face in that direction. Some of the patients have a Class II profile, that is, the mandible is in the back. The orthodontist looks at two aspects: the bite and the facial profile. There are mainly two types of treatment: one that can move only the teeth and then compromises the bite, or to enter into association with surgery, they move teeth to the jaw and all, when it comes to a correct bite, with correctly positioned teeth[10-12].

The integrity of the stomatognathic system (the elements are necessary but not enough) makes it particularly difficult to ascertain the exact muscular or articular cause of the changes in mandibular dynamics. In contrast to dental abnormalities of number and rash, in the maxillary compression there are evidenced morphofunctional changes that denote a complex disruption in the development Ap.DM. The common changing to all the framed cases denotes an insufficient transversal development of the dental arches (mono-or bi-maxillar), which is associated with facial and maxillary bone changes, disturbances of the intermaxillary reports or blockages of occlusion, functional deficits and disturbances[13-15]

The growth of the jaw arch through orthodontic treatment favours the resumption of nasal breathing and facilitates the normal development of growth. It fits in the German school classification; has two clinical forms: jaw compression syndrome with protrusion and dental and cramped spans. Maxillofacial jaw compression syndrome with denture protrusion and dilation is a class II malocclusion; it is a syndrome characterized by reducing the diameters of jaws, alveoli and teeth to the medio-sagital plan. The dento-alveolar process protrusion appears. Yet of intrauterine life a series of compressions exerted by the positions of the fetal limbs on the facial mass can produce jaw compressions, asymmetries of the newborn's face caused by uterine fibromas. Postnatal, surgical scars on the palatine arch are highlighted after interventions in congenital abnormalities and the absence of jaw growth sutures [1618].

Dental cavities and dental cavities complications are local pathological factors. Vicious habits act as determining factors by unbalancing intra- and extra-oral forces (oral breathing, atypical swallowing, finger sucking, tongue sucking, vicious habit rarely met).

It presents clinical manifestations: facial signs: adenoidian facies, the face is narrow and prolonged, with the wings of the nose flattened and hypotonic; a convex profile; pale teguments; wiped out cheeks, a blunt slit labia through which the upper incisors are seen ; in the speech and in the act of laughter the gingival mucosa is exposed; the higher incisors have dry enamel, are prominent, spaced, leaning against the lower lip; the upper lip is thin, pale, tilted to the boards; the lower lip is thick, cracked, blooming in the labio-mentonian groove; the lower level of the face is smaller. Oral signs: the dento-alveolar arcade has different shapes: omega (compression at the PM level); V (compression at IC level ); U (molar compression); trapeze at the lower arcade level ; M, W;palatine vault is deep up to very deep; the palatin torus is proeminent prominent; different degrees of mandibular distalisation; sagittal inoclusion; deep occlusion; open occlusion sometimes; periodontal affections [19-21].

Maxillary compression presents: high difficulty in mastication; limitation of the food incision; unilateral or bilateral hypotony of muscular nares; hypotony of the orbicular muscle of the upper lip; lower lip hypertonia; disturbed nasal breathing is characteristic; low narine tone, open labial slit, dry and cracked lips and an early cavity of frontal teeth are changes that correlate with oral breathing; In the first time of swallowing, the tongue exerts a pronounced pressure on the palatal faces of the upper incisors; sound changes: pellicular speech due to the narrow palatine vault;sigmatism - contour changes and continuity of dental arches; rhinolysis - narrowing or obstructing the nasal passage and some deficiencies when closing the lingvovelar diaphragm. The purpose of the treatmentis to moderate the increase in the middle of the face and to stimulate the development of the mandible in order to obtain balanced intermaxillar relationships with the soft parts. The prophylactic treatment consists of supervising the pregnant woman, feeding the child in the first 6 months; growth surveillance; combating vicious habits; prevention of tooth decay and its complications [22-24].

Removal of vicious habits:prior to the age of 2-3 years of age, thumb sucking would not be harmful to the development of W MD but after three years old bad habits are considered harmful actions.Deconditioning is mandatory and is performed with different procedures depending on age, child's psyche, entourage.After removing the obstacles, breathing re-training is done either by exercising only, or by associating devices to force the child to breathe through the nose (labial shield).

Orthodontic treatment. Orthodontic treatment with functional devices (Frankel type I and II apparatus, Balters type I and II bionator or activators); In cases of higher skeletal imbalances, myotherapy and mechanotherapyare used. Maxillofacial jaw compression syndrome is characterized by reducing premolar and molar diameters, through retrodence with the overcoating of the incisor group, accompanied by various degrees of dental crowding. The purpose of the treatment is to moderate the increase in the middle part of the face and to stimulate the development of the mandible in order to obtain balanced intermaxilar relationships with the soft parts. Removing bad habits: prior to the age of 2-3, thumb sucking would notbe harmful to the development of WMD, but after three years old bad habits is considered a harmful action. Deconditioning is mandatory and is done with different procedures, depending on age, child's psyche, entourage; can be done with: pijamas sleeves fastened around the arm and forearm; Pantyhose cuffs and trousers shoulder bindings with the help of tailor-made laces in appropriate position; mass educational methods and close supervision by staff [25-27].

The release of the nasopharyngeal air passage and breathing re-education: after the removal of the obstacles breath reeducation treatment is done either by exercising only, or by associating devices to force the child to breathe through the nose (the labial shield).

Curative treatment: orthodontic treatment with functional devices (Frankel type I and II apparatus, bionator Type I and II Balters, or with activators); In cases with higher skeletal imbalances, myotherapy and mechanotherapy are practiced; its name is class II malocclusion.

The determinism of the abnormality is genetically marked by a higher incidence of incision suture. The mild form presents morpho-functional and aesthetic disorders within the limits of tolerability, and in severe form occlusal imbalances produces periodontal disorders. 
Facial manifestations: The lower level/floor is normal or smaller; the labio-menton groove; prominent menton; thin lips; labyrinth occlusion is firm ; the nose is prominent. Oral Signs: the arcade may be trapezoidal, both superior and inferior dental crowding may vary from mild to severe forms; canines are in the vestibular -position; lower incisors may be in retro or pro inclination; various degrees of abrasion on palatal side; periodontal lesions; different degrees ofover coverage of the incisive group; different unilateral or bilateral premolar inversions; distal in the lateral area. Being of genetic nature it responds hardly to treatment or not at all.Risk of recurrence. Into thetemporary dentition it is not being treated. Election time for treatment is considered the first stage of mixed dentition [28-30].

The objectives of the treatment are: obtaining space; avoiding periodontal trauma; correcting relations in the lateral area; getting balanced and set up between the soft parts and balancing the skeleton -muscles units. The treatment consists of: pure functional therapy or in combination with extraoral devices; active mechanical therapy; mixed therapy, surgical-orthodontic treatment in combination with fixed therapy. In the jaw compression, a range of devices should be used depending on the therapeutic moment and the individual reactivity.

In temporary dentition, good results are also achieved with functional devices. In mixed dentition we start with active plates in the upper arch, and in the lower arcade with lingual arches. After active treatment with fixed devices, contention is done for several months with a plate, and the treatment ends with an activator. Succession of stages: active treatment, contention, final balancing.

Developing physical chemistry and biological chemistry in the process of inflammation

Using the achievements of these disciplines in pathology, allowed us to deepen the study of the inflammatory process. A physicochemical orientation has emerged in studying the inflammation process, which has been found in the physicochemical essence of inflammation (Schade).

The increasing metabolism in the inflammation site causes changes in the main physico-chemical properties of the tissue: isoionia, isotonia, izoonchia, isothermia.

It causes an increase in the concentration of hydrogen ions (H-hyperionia), increase of osmotic pressure (hypertonia), increase of oncotic pressure hypercholesterolemia), increase in temperature (hyperthermia) [31-33].

All these changes, commonly referred to as tissue hyperplasia, cause the development of hyperemia, exudation, migration, proliferation and condition the appearance of the main symptoms of the inflammatory process.

The physicochemical orientation in studying the inflammation process has uncovered a series of facts that have a role to play in developing this process. This conception has even sought to link the various phenomena found in the course of the inflammation process. An extremely dubious point, namely to what extent the mentioned physicochemical changes are the main factor in the occurrence of an inflammation process.All physicochemical changes characteristic of the inflammation process can be established only in the case of an already existing inflammatory process, and therefore have a secondary character.
The physico-chemical theory of inflammation also has an important shortcoming in that it attempts to reduce the inflammatory process to the laws of physical chemistry and colloidal chemistry [34-36]. Such an approach to the problem ignores the biological essence of the inflammatory reaction, and therefore has a mechanistic character[37]. From the point of view of physicochemical theory, inflammation remains an exclusively local process, overcoming the role of regulatory systems and mechanisms in the occurrence of the inflammation process, and especially the importance of the nervous system.

\section{Experimental part}

\section{Materials and methods}

The study included a total of 27 cases of jaw compression and benefited from orthognatal surgery in the Maxillofacial Surgery Clinic between 2015-2018.

In order to achieve the targets for an individual treatment crucial are: the precision of move orthodontic prediction, stable results in orthognatic surgery, postsurgical care or predictability of adequate postsurgery orthodontic movements.

\section{Results and discussions}

The patient is unique, an unrepeatable entity with its own pathology, and therefore individualisation of treatment is the first consideration of the physician when setting the treatment plan.

Orthognatical surgery involves the surgical manipulation of the elements of the facial skeleton to resolve the correct anatomical and functional relationship of the patients with the dental-facial abnormalities.

Correction operations are in combination with orthodontic treatment by surgery specific procedures, resulting in the correct positioning of the jawbone so to give a correct bite functionality and a harmonious facial profile.

The operation has the effect of improving breathing, orthognatic surgery being the mostappropriate therapeutic method.

Of the 27 patients under study, 19 patients (70.37\%) are urban and 8 (29.62\%) come from rural areas.

The standard protocol for maxillary compression includes three stages: an orthodontic treatment preparatory to surgery, surgery on one or both of the jaws and the orthodontic completion by optimizing the bite. Surgery is done through the mouth, avoiding any scars on the outside. The procedure is under general anesthesia and lasts between 2 and $5 \mathrm{~h}$, depending on its complexity. Modern technology makes it possible the opening of the mouth immediately after surgery, resuming the masticatory function, eliminating the incidence of the immobilized jaws for 4-6 weeks, specific to the classic surgical approaches. Thus, it is possible to immediately evaluate the outcome and reduce the postoperative recovery period to 10-14 days. Complete treatment lasts between 18 and 24 months, depending on the difficulty of the case. Before the orthognatic surgery takes place, the patient will need orthodontic or dental treatment. This will allow the teeth to be aligned in a position that allows the repositioning of the jaw bone to become more stable after the orthognatic operation.

No rmally, the patient needs orthodontic treatment for one or two years to decompensate teeth before reconstructive orthognatic surgery. Dental extractions are also carried out before. 
Three treatment objectives are fundamental in orthognatic surgery: functionality, aesthetics, and stability. These three objectives are primary goals in treating patients.

Surgery is done through the mouth, avoiding any scars on the outside. The procedure is under general anesthesia and lasts between 2 and $5 \mathrm{~h}$, depending on its complexity. Modern technology makes possible the opening of the mouth immediately after surgery, with resuming the masticatory function, eliminating the incidence of immobilized jaws for 4-6 weeks, specific to classical surgical approaches. Thus, it is possible to immediately evaluate the outcome and reduce the postoperative recovery period to 10-14 days. A complete treatment lasts between 18 and 24 months, depending on the difficulty of the case.

Orthognatic surgery, especially in the jaw, is bloody. Unlike other interventions where bleeding can be controlled with diathermy and blood vessel ligation, the bleeding resulting from orthognatic surgery cannot benefit from such measures. There is often a slow loss of blood during the operation, which can be controlled by pressure applied to the incision site. Using hypotensive anesthesia, by lowering blood pressure, helps enormously in reducing the amount of lost blood. This helps for a faster recovery.

\section{Conclusions}

Dental arcade cracking has reduced cross-sectional dimensions, being the result of insufficient development of the dental arcade, butsecondary deformation is possible under the action of etiopathogenic factors. Within the limits of normal development, the transverse dimensions of the dental arches are variable from individual to individual, therefore, in order to objectify the changes, we used the index method, which compares the width of the arcade to other elements of the subject as a criterion of appreciation. The diagnosis and treatment plan will be determined by the orthodontist specialist after a consultation. The physician will also indicate complementary exams such as: study models, orthopantomography and lateral teleradiography after which the doctor will diagnose and will make the treatment plan. Functional disorders caused by jaw compression are noted in breathing, mastication, swallowing, phonation and muscle tonus.

\section{References}

1.COLLINS P. Introduction and Systemic Overview. Embryogenesis. In: Standring S, editor. Gray's Anatomy. 39th ed. Edinburg: Elsevier Churchill Livingstone; 2005.p.191-210.

2.GRIGORESCU-SIDO Fr. Embriologie generala si speciala. ClujNapoca: Casa cãrbi de tiinjã;2006.p.39-40,50-57,106-116,142-148,259291.

3.SADLER TW. Langman's Medical Embryology. 10th ed. Philadelphia: Lippincott Williams and Wilkins; 2006.p.65-87,171-99,363-403,433-83. 4.BARLEAN, L.M., AUNGURENCEI, A., AUNGURENCEI, O., SCUTARIU, M.M., BALCOS, C., MOISE, M., Rev. Chim. (Bucharest), 66, no. 11, 2016, p. 1877-1880

5.LARSEN JW. Embryologie humaine. 3e ed. Bruxelles: De boek\&Larcier; 2003.p.67-79,349- 454.

6.COLLINS PATRICIA. Head and Neck. In: Standring Susan, editor. Gray's Anatomy. 39th ed. Edinburg: Elsevier Churchill Livingstone; 2005.p.447-53, 493-5, 609-16.

7.GILBERT-BARNES E, DEBICH-SPICER DE. Handbook of Pediatric Autopsy Pathology. New Jersey: Humana Press; 2005.p. 347-371.

8. CALIN, A.M., DEBITA, M., CIURCANU, O.M., SCUTARIU, M.M., SZALONTAY, A.S., Xerostomia and Hyposalivation in Patients with Physical and Psychological Disabilities, Rev. Chim.(Bucharest), 68, 2017, p. 2443-2447

1388
9.LACBAWAN F, MUENKE M. Central Nervous System Embryogenesis and Its Failures. Pediatr Devel Pathol 2002;5:425-47.

10.PERKIOMAKI M. Craniofacial shape and dimensions as indicators of orofacial clefting and palatal form. Lucrare de dizertatie. Universitatea Oulu 2008.p.17-23.

11.BARTECZKO K, JACOB M. A re-evaluation of the premaxillary bone in humans. Anat Embriol 2004;207:417-37.

12.ANTOHE, M.E., FORNA AGOP, D., DASCALU, C.G., Implications of digital image processing in the paraclinical assessment of the partially edentated patient, Rev. Chim. (Bucharest), 69, no. 2, 2018 p.521-524 13. BARLEAN,L., TATARCIUC,M., BALCOS, C., VITELARIU, A.M., MOISEI, M., CHISCOP, I., SCUTARIU, M.M., Dentists Occupational Exposures to Chemicals During Hands Hygiene in the Dental Offices in lasi, Rev. Chim.(Bucharest), 66, no. 10, 2015, p. 1696-1699

14.NICULESCU,O.,NICA,P., GURLUI,S.,et al., Experimental investigations of polymer plasma laser ablation, Mat. Plast., 46, no. 3, 2009, p.336-338

15. SCUTARIU, M.M., DANILA, V., CIUPILAN, C., CIURCANU, O.E., Semiology of the Pain Syndrome-Identifying the Ideal Methods of Locoregional Anesthesia Based on Their Rationale and Features, Rev. Chim.(Bucharest), 68, no. 10, 2017, p. 2373-2377

16. VASLUIANU, E., POPESCU,V., GRIGORIU,A., et al., Comparative study concening the FIR Analysis and the performances of chitosan based wrinkle-proofing agents, Rev. Chim. (Bucharest), 64, no.10, 2013, p.1104-1115

17. NASH,D.,RUOTOISTENMAKI,J ., ARGENTIERI,A.et al.,Profil of the oral healhcare team in countries with emerging economies,Conference Global Congress on Dental Education location,Dublin,Ireland, European J ournal of Dental Education,12((1), 2008, pg.111-119

18. POPESCU,V., VASLUIANU,E., FORNA,N.C., et al., Comparative study of the FTIR Analysis and the peformances of N,N,N-trimethyl chitosan as wrinke-poofing agent Rev. Chim. (Bucharest) ,64, no.11,2013, p.1284-1294

19. BOTNARIU,G., FORNA, N., POPA,A., et al., Correlation of glycemic control parameers in non-diabetic persons with cardiovascular risk scores-results from a cross-sectional study, Rev. Chim. (Bucharest), 8, no. 1,2017, p.108-110

20. MIHAELA MONICA SCUTARIU, CORINA CIUPILAN, MIHAELA SALCEANU, ANCA MELIAN, DORIANA AGOP FORNA, IOANA SIOUSTIS, OANA CIURCANU, Incidence of dento-periodontal pathologyin geriatric patients, Romanian Journal of Oral rehabilitation, 2018, 10 (1), 128132

21. ILIESCU-BULGARU,D.,COSTEA,G., SCRIPCARU, A., etal., Homicide and alcohol consumption.A medico-legal and psychiatric interdisciplinary appoach.Multivariate analysis, Romanian Journal of legal medicine, 23(2),2015, pg.137-142

22.DELIA HINGANU, MIHAELA MONICA SCUTARIU, MARIUS VALERIU HINGANU, Annals of Anatomy-Anatomischer Anzeiger, 2018, 218, 271275

23.IFTENI,G., APOSTU,A., TANCULESCU,O., Dental occlusion and the importance of is proper investigation-partll, Romanian Journal of Oral Rehabilitation, 8(4),2016,pg.17-22

24. JUMANCA, D., GALUSCAN,A., PODARIU,A.C., et al.,Antiinflammatory action of oothpastes conaining betulin nanocapsules, Rev. Chim. (Bucharest), 65, no. 12, 2014, p.1473-1476

25. BALAN, G., GRIGORE, C.A., BUDACU,C.C., et al., Antisepsis, Desinfection Sterilization -mehods used in dentistry, Rev. Chim. (Bucharest), 68, no.1, 2017, p.186-191

26. MIHAELA MONICA SCUTARIU, IORDANIS SALAMASTRAKIS, CRISTINEL IONEL STAN, ALIN HORAPIU NEDELCU, LIVIU CIPRIAN GAVRIL, CLAUDIA FLORIDA COSTEA, ANA MARIA DUMITRESCU, ANCA SAVA, ELENA SAPTE, Histopathological consequences of hyperzincemia on rat teeth. Experimental study, Rom J Morphol Embryol, 2016, 57 (3), 1057-1061

27.ZEGAN, G., DASCALU, C.G., MAVRU, R.B., Cephalometric, features of Class III malocclusion, Medical-surgical journal,119(4), ,2015, 11531160; 
28.GRADINARU, I., IGNAT ,L., DASCALU, C.G., SOROAGA, L.V., ANTOHE,M.E., Studies regarding the architectural design of various composites and nanofibres used in dental medicine, Rev. Chim. (Bucharest), 69, no. 2, 2018, p.328-331

29.0ANA-ELENA CIURCANU, DORIANA AGOP FORNA, CRISTINA POPA, MIHAELA MONICA SCUTARIU, Implementation of methods of locoregional anesthesia in dental surgery, Romanian Journal of Oral rehabilitation, 2017, 9 (4) , 120-127

30.ANCUTA ,C., POMIRLEANU, C., IORDACHE,C., et al., Serum lipid profile in diffuse versus limited systemic sclerosis data from the SASS cohort, Rev. Chim. (Bucharest), 69, no. 2, 2018, p.403-406

31.BUDACU, C., NEMTOI, A., CONSTANTIN, M., Biomaterials used in Reduction and Fixation of Unstable Fractures of the Zygomaticomaxillary Complex, Mat. Plast., 54, no. 4,2017, p.773-776 32.NITESCU D., MIHAI C., OANTA C., Evaluation of cumulative effects of chemotherapy and bevacizumab (avastin) in oncological patients with periodontal disease,Rev. Chim. (Bucharest), 68, no. 3,2017, p. 549

33.BUDACU, C.C., CIORANU,S.V.,CHISCOP, I.,e al., Glucocoricoids and postoperative disease in oral-maxillofacial surgery, Rev. Chim. (Bucharest), 68, no. 11, 2017, p.2716-2719

34.TARANU , T., CONSTANTIN, M.M., TOADER, M.P, et al., The benefits of using the lodine solution in the treatment of acne at pregnant women,Rev. Chim. (Bucharest), 69, no. 9, 2018, p.2343-2345

35.GRIGORE, M., FURNICA, C., ESANU, I., et al., Pentalogy of Cantrell associated with unilateral anophthalmia .Case report and literature review, Medicine, 97(31),2018

36.NEMTOI, A., DANILA ,V., DRAGAN, E., et al., The effecs of insulin and strontium ranelate on guided bone regeration in diabetic rats, Rev. Chim. (Bucharest), 68, no. 4, 2017, p. 693-697

37.PLESOIANU C.E., ANDRIESCU G., SALARU,D., etal., The relationship beween biochemical variables and the quality of life in paiens with chronic heart failure,Rev. Chim. (Bucharest), 68, no.10, 2017, p..24522458;
38.SALARU,D., MACOVEI,L., STATESCU, C., Assessment of microalbuminuria in hypertensive patients wih established coronar artery disease, Revista Romana de Medicina de Laborator, 21(4), 2013, pg.407-414

39.MARTU,I., LUCHIAN,I., DIACONU-POPA, D. et.al., Clinical and technological particularities regarding unidental restoration using ceramic crwns with a zirconia infrastructure.a case report,,Romanian J ournal of Oral Rehabilitation,9(1),2017, pg.27-31.

40.ANCUTA,C., POMARLEANU,C., IORDACHE C., Periodontal disease and lipid profile in systemic sclerosis: an EUSTAR Cohot Expeience, Rev. Chim. (Bucharest), 68, no. 4, 2017, p.890-893

41.IORDACHE ,C., GHIORGE,C.A., ANTOHE M.E., et al., Temporomandibular joint involvement in rheumatoid arthritis and ankylosing spondylitis:a cross-sectional study, 994), 2017, pg.40-46

42. MURARIU,A., PRICOP M., BOBU,L., et al., Ethics dimensions in dentistry, Romanian J ournal of Oral Rehabiliation,8(1), 2016,pg.65-71 43.POPA , C., STELEA C.G., FILIOREANU,A.M., et al., PCR Analysis of the Herpesviruses presence in crevicular fluid in HIV-positive patients, Rev. Chim. (Bucharest), 68, no. 11, 2017, p. 2672-2675 44.BALCOS,C., BARLEAN, M.C., BOBU, L., etal., Evaluation of infection control knowledge and attitudes among dental technicians in Iasi, Romanian journal of Oral Rehabilitation, 10(1),2018, pg.80-87

45.FORNA AGOP ,D., POPESCU, E., COSTAN V., V., et al.,Conventional maxillary reconstruction using service obturators, Romanian J ournal of Oral rehabilitation, (8),3,2016, pg.32-39

46.COSTACHE ,I.I., COSTEA .C.F, DANCIU,M., COSTAN, V.V., AURSULESEI,V., DUMITRESCU,G.F., TURLIUC, M.D,SAVA ,A., Amyloidosis-a rare cause of refractory heart failure in a young female, Rom J Morphol Embryol, 2017,58(1),201-2016

Manuscript received: 13.09 .2018 